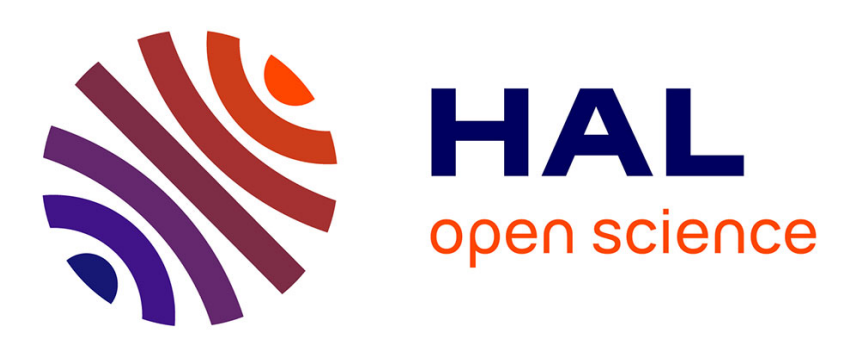

\title{
Short and Long-Term Evaluation of Efficiency and Quality. An Application to Spanish Municipalities
}

Maria Teresa Balaguer, Diego Prior

\section{To cite this version:}

Maria Teresa Balaguer, Diego Prior. Short and Long-Term Evaluation of Efficiency and Quality. An Application to Spanish Municipalities. Applied Economics, 2009, 41 (23), pp.2991-3002. 10.1080/00036840701351923 . hal-00582131

\section{HAL Id: hal-00582131 \\ https://hal.science/hal-00582131}

Submitted on 1 Apr 2011

HAL is a multi-disciplinary open access archive for the deposit and dissemination of scientific research documents, whether they are published or not. The documents may come from teaching and research institutions in France or abroad, or from public or private research centers.
L'archive ouverte pluridisciplinaire HAL, est destinée au dépôt et à la diffusion de documents scientifiques de niveau recherche, publiés ou non, émanant des établissements d'enseignement et de recherche français ou étrangers, des laboratoires publics ou privés. 


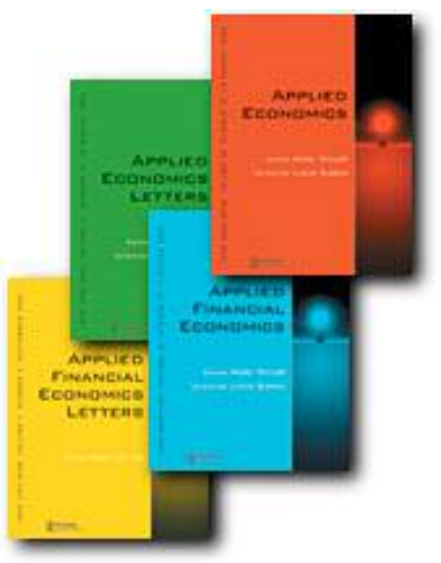

Short and Long-Term Evaluation of Efficiency and Quality. An Application to Spanish Municipalities

\begin{tabular}{|r|l|}
\hline Journal: & Applied Economics \\
\hline Manuscript ID: & APE-06-0314.R1 \\
\hline Journal Selection: & Applied Economics \\
\hline JEL Code: & $\begin{array}{l}\text { D60 - General < D6 - Welfare Economics < D - Microeconomics, } \\
\text { Local Government|Intergovernmental Relations < H - Public } \\
\text { Economics, H71 - State and Local Taxation, Subsidies, and Revenue } \\
<\text { H7 - State and Local Government|Intergovernmental Relations < } \\
\text { H - Public Economics }\end{array}$ \\
\hline Keywords: & $\begin{array}{l}\text { Local government performance, Data Envelopment Analysis, } \\
\text { Efficiency, Quality }\end{array}$ \\
\hline \hline
\end{tabular}

\section{s) ScholarONE" \\ Manuscript Central}




\title{
SHORT AND LONG-TERM EVALUATION OF EFFICIENCY AND QUALITY. AN APPLICATION TO SPANISH MUNICIPALITIES
}

$\mathrm{M}^{\mathrm{a}}$ Teresa Balaguer-Coll $\dagger$

May, 2006

\author{
Diego Prior $\$$
}

\begin{abstract}
This article analyses efficiency and quality levels in Spanish local governments and their determining factors through the application of the Data Envelopment Analysis (DEA) methodology. It aims to discover to what extent inefficiency arises from both quality considerations and external factors beyond the organisation's control, or alternatively, how much inefficiency is due to inadequate resource management. As a component of inadequate resource management, we test the existence of politicalbudgetary cycles in the temporal evolution of inefficiencies. The results show that on the whole there is still a wide margin within which local government efficiency and quality levels could be increased, although it is revealed that a great deal of inefficiency is due to exogenous or non-controllable factors. In particular, it has been found that the size of the municipality, the per capita tax revenue, the per capita grants and the amount of commercial activity are some of the factors related with local government efficiency.
\end{abstract}

Keywords: Local government performance, Data Envelopment Analysis, Efficiency and Quality.

JEL Classification: D60, H71, H72

Communications to: $\mathrm{M}^{\mathrm{a}}$ Teresa Balaguer-Coll, Departamento de Finanzas y Contabilidad, Universitat Jaume I, Campus del Riu Sec, 12071 Castellón, Spain. Telf. +34 964728570, e-mail:bcoll@uji.es

$\uparrow$ Universitat Jaume I

\& Universitat Autònoma de Barcelona 


\section{Introduction}

The constitution of the European Monetary Union has implied the unavoidable requirement to control the deficits of the public sector budgets for member states. This means that there is substantial pressure to reduce expenses (obviously, it can also be a question of increasing revenues, but we deal herein with expenses). Reducing expenses can be achieved by making three decisions: a) reducing the provision of public services, b) reducing their quality or c) controlling the inefficiencies found.

In this paper, we focus on the third measure because an increase in productivity will be decisive in the sustainability of public sector organisations, and it will entail the smallest social impact at the same time. An increase in efficiency and productivity is no easy task, and from a socio-economic point of view, there are times when their effects are precisely the opposite to those desired. An example of this is the following scenario: let us assume that public managers are defining the strategic decisions to curb deficits in a local transport service. The decisions to be made are: a) elimination of the nonprofitable lines from a financial point of view, b) reduction of the service frequency and c) increase in productivity (by either increasing the number of kilometres per employee or the hours of use per bus) without the quality of the services being affected. Decision a) can involve major social costs if certain population segments are left without a basic public service; decision b) implies a deterioration of quality and it can give rise to a supplementary deficit on a long-term basis; finally, decision c) preserves output and quality of service while attempting to increase efficiency and productivity. 
This example illustrates the main objective of this article: i.e. to observe what possibilities there are of increasing the efficiency of a sample of Spanish municipalities by trying to reduce the excess of input consumption, while at the same time maintaining the services provided to the population and verifying what the trade-offs exist between efficiency and quality when we account for quality variables. Considering the short- and the long-term temporal dimension of efficiency is also an objective that will be dealt with in the following pages.

Local government plays an important role in the provision of public services ${ }^{1}$, and forms a sub-sector that has taken on more responsibilities over time (see Table 1 for the responsibility levels of central, regional and local administration). This in turn has led to an accumulation of operations, and a consequent increase in expenditure and greater specific weight in the country's economy. In the Spanish experience, following the approval of the 1978 Constitution, important changes have been experienced which have led to an increase in the responsibilities of state and local governments in the provision of public services.

[Table 1 about here]

Local government is precisely our main objective. In this paper we analyse the levels of both efficiency and quality in these organisations, and determine what financial, socioeconomic and budgetary characteristics are common in local governments with a similar efficiency. In this way, we will be able to discover whether inefficiencies can be explained by external factors, and as such, whether they are beyond the control of the

\footnotetext{
${ }^{1}$ For an excellent study of public sector efficiency, see Fox (2001).
} 
authorities, or they are due solely to bad management. A further possibility is that inefficiency may be due to a combination of both aspects.

If we take into account the data we have, as set out below (in Section 3), part of the variables related to quality are categorical. As they are non-continuous variables, a suitable procedure to deal with this type of variable has had to be established. We have taken the proposal set out by Banker and Morey (1987) from existing alternatives as we consider it to be the most suitable because it takes into account the characteristics of our sample.

The following pages are divided into five sections. Section 2 sets out the methodology used in the efficiency analysis. The sample of local authorities analysed and the variables defined are presented in Section 3. Section 4 presents the results of the empirical analysis and Section 5 analyses factors affecting the inefficiency found. Finally, Section 6 presents the essential conclusions drawn from the study.

\section{Description of the methodology}

The choice of the DEA (Data Envelopment Analysis) model for the analysis of local government efficiency is owing to its conceptual simplicity and its versatility, both of which allow many of the difficulties inherent in the evaluation of the management in public services to be eliminated. Amongst these difficulties, the multi-product nature and the fact that market prices do not exist are the most important issues when evaluating public service institutions. 
Although there is an abundant presence of literature, involving empirical applications based on the analysis of efficiency using Data Envelopment Analysis methodology to the public sector ${ }^{2}$, studies into local government efficiency are still limited. For a survey of efficiency in local government see Worthington and Dollery (2000).

The DEA model is a mathematical programming model that enables an efficiency analysis to be carried out, which is subject to a series of restrictions. More often than not within the public sector, outputs are either totally or partially set externally, and for this reason, it makes more sense to evaluate efficiency in terms of the minimisation of inputs. Therefore, the mathematical formulation of the DEA in the so-called input orientation version, can be expressed as follows:

$$
\begin{gathered}
\operatorname{Min}_{\theta, \lambda} \theta \\
s . a . \quad-y_{i}+Y \lambda \geq 0 \\
\\
\theta x_{i}-X \lambda \geq 0 \\
N 1^{\prime} \lambda=1 \\
\lambda \geq 0
\end{gathered}
$$

where $\theta$ represents the coefficient which proportionally reduces the inputs of the evaluated unit, and its value measures the efficiency of unit ' $i$ ' subject to evaluation (Decision-Making Unit, or $D M U$, is the term used in the literature on this subject). $X$ and $Y$ are defined as the input and output matrices which contain all the units (DMUs) to

2 Such as public schools (Noulas and Ketkar, 1998; Ray, 1991), hospitals (Chang, 1998; Pavlova et al., 2004), police service (Diez-Ticio and Mancebon, 2002) and courts (Pedraja and Salinas, 1996), among others. 
be evaluated, while $x_{i}$ and $y_{i}$ represent observed inputs and outputs corresponding to the $D M U$ under evaluation. Finally, $\lambda$ is the activity vector which describes the importance of the DMUs considered to determine the virtual reference which is used as a comparison in order to evaluate unit ' $i$ '.

Programme [1] has to be defined the same number of times as there are units to be evaluated (once for each $D M U$ ). The DEA methodology defines a linear programme that compares each producer with the "best" producers which make up the "best practice frontier". The key to the analysis consists of finding the best virtual DMU for each real DMU. The model sets out with two sets of restrictions: the first $\left(Y \lambda \geq y_{i}\right)$, forces the virtual DMU to produce at least as many outputs as those obtained by the DMU under analysis. The second restriction $\left(\theta x_{i} \geq X \lambda\right)$ enables us to determine the lowest possible input consumption.

By resolving the linear programming corresponding to each one of the units under study, we obtain a coefficient $\theta$ for each DMU. If $\theta_{i}$ is equal to one, then the DMU is defined as efficient, ${ }^{3}$ while in the remaining cases, i.e. when $\theta_{i}<1$, it indicates an inefficient performance in relation to the units located at the frontier.

The underlying technology in programme [1] exhibits constant returns to scale. In other words, there is no restriction to compare $D M U s$ with a low (high) size with other units of a superior (inferior) size. In this way, the activity vector $\lambda$ shows whether the best practice frontier is made up of either smaller (if $\lambda>1$ ) or larger sized units (if $\lambda<1$ ) than

\footnotetext{
${ }^{3}$ The literature describes this situation as one of poor efficiency. A more robust definition, based on Pareto's optimality concept, requires additional conditions. An excellent presentation of the various notions of efficiency can be found in Cooper, Seiford and Tone (2000).
} 
the evaluated $D M U$. More suitable technological assumptions can also be introduced. Thus, if we wish to consider only units of a similar size to that of the evaluated $D M U$, we can introduce the assumption that the variable returns to scale. This only requires adding one further restriction to programme [1]:

$$
\sum_{i=1}^{I} \lambda=1
$$

Expressions [1] and [2] describe the standard DEA methods. In our case however, an adaptation is required in order to introduce two specific aspects: a) the consideration of quality as a new variable, which differs to those of inputs and outputs and b) the consideration of part or all of the quality variables as qualitative variables. We now go on to discuss how we defined the model that is implemented.

\section{Sample selection and variables definition}

In order to carry out the analysis, statistical information from the Valencian Audit Commission and the Spanish Ministry for Public Administration was used. Outputs were obtained from information compiled in a survey of local infrastructure and equipment devised by the Spanish Ministry for Public Administration (MAP), while inputs came from the budget of local authorities taken from the Valencian Audit Commission. The sample was thus made up of 258 municipalities and the period under analysis was 1992 to 1995. 
It is important to highlight the fact that when the data were selected, a decision to use real expenditures and revenues (observed net charges and observed net liabilities) instead of forecasts was made, although in some cases, these were at the price to be paid to be up to date due to publication delays. However, the use of budgeted data would have greatly distorted the conclusions, since it is well known that in terms of general bureaucratic behaviour, budgeted figures generally underestimate expenditure and overestimate revenues.

In output specifications we differentiate production variables on the one hand, and quality variables on the other. The information available on the variable of the quality of services provided is of a categorical nature (the quality of the services offered is arranged in three classifications: good, normal or bad). It is quantified using the proposal set out by Banker and Morey (1986), which involves breaking down the quality variable into two categorical variables: $d_{1}$ and $d_{2}$. Thus, the values taken by $d_{1}$ and $d_{2}$ will be the following for one unit $j$ :

$$
\begin{aligned}
& d j_{1}=d j_{2}=0, \text { if the quality is bad. } \\
& d j_{1}=1 \text { and } d j_{2}=0 \text {, if the quality is normal. } \\
& d j_{1}=d j_{2}=1, \text { if the quality is good. }
\end{aligned}
$$

In terms of outputs, the specification of variables has been representative of the essential services provided by local councils. With the aim of setting limits on what essential services are, we firstly refer to Spanish Municipal Law where we have found the minimal services required (Table 2 contains these services). The descriptive statistics corresponding to these variables are presented in Table 3. 
[Table 2 about here]

[Table 3 about here]

Given the difficulty of quantifying public sector output, it is often essential to look for reasonable proxy variables. Initially, and based on the work of De Borger and Kerstens (1996a, b), Taïrou (2000) and Vanden Eeckaut (1993), the number of inhabitants is chosen to reflect the basic services provided to the local population.

However, there are municipalities with specific situations (characterised by low population density, having a major road network, high quality public services) that require more ad hoc variables. This is the reason why alternative variables are worth considering as observed outputs. In order to analyse to what extent there are other variables explaining the cost variability for each municipality, we estimate a CobbDouglas cost function as follows ${ }^{4}$ :

$$
T C=f\left(y_{1}, y_{2}, y_{3}, y_{4}, y_{5}, a_{1}, a_{2}\right)
$$

where,

TC: Total cost

$y_{1}$ : Population

$y_{2}$ : Number of lighting points

$y_{3}:$ Tons of waste collected

$y_{4}$ : Street infrastructure surface area

\footnotetext{
${ }^{4}$ The Cobb-Douglas cost function also includes input prices. However, as in De Borger and Kerstens (1996a), we do not have information about input prices. Accordingly, we ignore the variations in input prices. This assumption is not too unreasonable when the rigidity of salaries in the Spanish public sector is taken into account.
} 
$y_{5}$ : Registered surface area of public parks

$a_{1}$ : Citizens' evaluation of quality: number of votes

$a_{2}$ : Technical quality of public infrastructures

The estimation of (3) has taken natural logarithms in order to determine a CobbDouglas functional form and to express the coefficients as the cost elasticity indicator corresponding to each variable. Before we go on to estimate the regression models, we were interested in ascertaining the existence of any possible multicolinearity, and we analysed the degree of linear association between each pair of variables using Pearson's linear correlation coefficient. The most outstanding result was that the variable "population" is that which presents the greatest correlation to the rest. Therefore, in order to avoid multicolinearity problems, we have estimated a model with the variable "population" on the one hand, while the rest of the variables are included in another model. The results of the multiple linear regression analysis are shown in Table 4.

[Table 4 about here]

The explanatory power of the regression models as a whole is good, since adjusted $R^{2}$ presents very high values. However, when the adjusted $R^{2}$ for Model 2 (adjusted $R^{2}=0.914$ ) is compared with Model 1 (adjusted $R^{2}=0.921$ ), we can conclude that population is a very good variable to explain the variation in the dependent variable. However, we cannot take these results as conclusive because Model 1 presents a situation of slightly increasing returns to scale while Model 2 exhibits a technology with 
decreasing returns to scale ${ }^{5}$. The use of ordinary least squares along with the presence of inefficiency may likely explain these apparently contradictory results.

Before defining the input variables used, it should be pointed out that we chose to carry out two types of evaluation: short-term and long-term frontiers. The short-term frontier is referred to when a frontier for each year is estimated. On the other hand, when the long-term frontier is determined, the budget outcomes from the expenditure of 1992 to 1995 are added, and the aggregated service provision process of this period is evaluated. In other words, by using terms set down by OECD (1997), we evaluate the efficiency within a long-term budgetary framework.

There are two reasons for estimating both types of frontier. Firstly, it enables us to verify the existence of the so-called "political-budgetary cycles" (Rogo,1990) if significant differences are observed between the levels of annual efficiency and the accumulated value for the legislative period analysed. Secondly, as the number of votes in one of the specifications is obtained by the governing political party during the previous legislature, and is introduced as a quality "proxy", it logically follows that this satisfaction derives from a whole legislative period, and not from one particular year.

Thus, in order to determine local authority behaviour in the local government, three different combinations of DEA models have been applied which depend on the corresponding variables specification. These models are the following:

- Model DEA 1, the output specifications taken are production variables.

\footnotetext{
${ }^{5}$ In both models we can reject the null hypothesis of constant returns to scale.
} 
- Model DEA 2 includes two quality attributes: $a_{1}$, the variable "level of citizen satisfaction" (subjective appreciation of quality by the population), defined as the number of votes obtained in the current municipal elections by the party in power in the previous elections; and $a_{2}$ as the variable "quality of services" (the objective quality of local authority infrastructures).

- Finally, in Model DEA 3, all variables are included (both production and quality attributes). This is the most thorough model, which enables us to evaluate both efficiency and quality at the same time.

\section{INPUT VARIABLES:}

$x_{1}$ : Wages and salaries

$x_{2}$ : Operating expenditure

$x_{3}$ : Current and capital transfer

$x_{4}$ : Capital expenditure

\section{OUTPUT VARIABLES CORRESPONDING TO MODEL DEA 1:}

$y_{1}$ : Population

$y_{2}$ : Number of lighting points

$y_{3}$ : Tons of waste collected

$y_{4}$ : Street infrastructure surface area

$y_{5}:$ Public parks surface area

\section{OUTPUT VARIABLES CORRESPONDING TO MODEL DEA 2:}

$y_{1}$ : Population 
$a_{1}$ : Number of votes obtained in elections by the political party in power during the previous legislative period.

$a_{2}$ : Quality of services (dichotomous: $a_{21}$ and $a_{22}$ )

\section{OUTPUT VARIABLES CORRESPONDING TO MODEL DEA 3:}

$y_{1}$ : Population

$y_{2}$ : Number of lighting points

$y_{3}$ : Tons of waste collected

$y_{4}$ : Street infrastructure surface area

$y_{5}:$ Public parks surface area

$a_{1}$ : Number of votes obtained in elections by the political party in power during the previous legislative period.

$a_{2}$ : Quality of services (dichotomous: $a_{21}$ and $a_{22}$ )

\section{Results obtained from the application of the efficiency and quality frontier to the sample of municipalities analysed}

In order to carry out the evaluation defined in the previous Section, programme [1] was first applied to all the local authorities in the sample. The coefficient obtained (with a technological assumption of constant returns to scale) enabled us to determine the socalled Global Technical Efficiency coefficient (GTE). Programme [1] was applied once more, but the weight restrictions mentioned in Section 2 were introduced on this occasion, and the Pure Technical Efficiency coefficient (PTE) was obtained in a 
technological context of variable returns to scale. Finally, the Scale Efficiency (SE) was determined by relating GTE and PTE $(\mathrm{SE}=\mathrm{GTE} / \mathrm{PTE})$.

Tables 5, 6 and 7 present a synthesis of the obtained results. GTE was between $66 \%$ and $75 \%$, PTE was between $75 \%$ and $89 \%$ and the inefficiency due to scale, caused by deviations from optimal size of the organisation, was around $8 \%-24 \%$, depending on the different output specifications. In this way, the organisations have to accept a level of inefficiency that varies between the $77 \%$ point and the $92 \%$ point, which is furthermore difficult to correct owing to the fact that adjustment of the size of the organisation is complicated.

[Table 5 about here]

[Table 6 about here]

[Table 7 about here]

From the total sample, 201 municipalities are above optimal size, indicating that decreasing returns to scale prevail. In addition, in order to verify whether significant differences in efficiency levels occurred between the initial period and the final period, Wilcoxon's non-parametric test was applied. The results indicate that the differences in averages between groups are significant at a reliability level of $90 \%$. This test confirms the existence of the aforementioned political-budgetary cycles, consisting of an increase in spending in the final years of office of a given political party. 
After a global analysis, we now concentrate on the distribution of the coefficients according to size. GTE covers all organisations, irrespective of their size, and the results indicated that local authorities with populations of 5,000 and 20,000 showed a higher GTE in practically all the output specifications. Such a result could indicate this population band as being the optimum size for an organisation to be considered efficient. When considering the PTE coefficient, inefficiency grows in municipalities with a lower number of inhabitants. Out of those organisations with a population of over $5,000,21.33 \%$ are efficient in all output specifications, whereas only $15.93 \%$ of the populations under 5,000 inhabitants are efficient. Finally, Scale Efficiency goes down as the number of inhabitants grows, which suggests that if all technical inefficiency has been removed, then the level of inefficiency is impossible to correct without modifying the dimensions of the organisation.

These results can be interpreted as follows: The optimum size corresponds to relatively small municipalities, since the scale inefficiency is lower in the under 5,000 population band. However, larger municipalities are nearer to the frontier. In other words, although they are not the optimum size, they have better and greater resources (qualified staff, better information technology resources etc.), which place them very close to the variable returns to scale frontier (this situation is depicted in Graph 1).

[Graph 1 about here]

\section{Determining factors of technical inefficiency}


After the results analysis, it is interesting to pay attention to the factors that affect the levels of inefficiency. Firstly, we tested whether the budget structure has any influence on the inefficiency of the municipalities, and secondly, we ran a regression analysis in order to determine the importance of external factors affecting inefficiency.

We start with the first factor. The hypothesis to be tested is whether the budget structure, which has certain rigidities as a result of unavoidable legal compromises for most of the time (strong dependence on some revenues, the structure of the public servant collective, some long-term agreements contracting out specific services...), introduces inefficiencies as a consequence of legal restrictions to change within the organisation. To some degree, if this hypothesis is accepted, part of the inefficiencies found is related to the inefficiencies in fund allocation as a result of the impossibility of change in the short-term application of the municipalities' expenses. Otherwise, if the null hypothesis cannot be rejected, we have to accept that the budget composition has an insignificant bearing on whether the local authority is classified as efficient.

We used the Finger and Kreinin's similarity index (1979) to carry this out. This index has been used in the field of international commerce, and is represented by the following expression when applied to the case in point:

$$
S(a b)=\sum_{i}\left\{\operatorname{Min}\left[x_{i}(a), x_{i}(b)\right]\right\} * 100
$$

In our study, $S(a b)$ measures the similarity between the two DMUs $a$ and $b$ with regard to the budgetary structure of expenditures and revenues. $X_{i}(a)$ and $X_{i}(b)$ represent the percentages of item $i$ in organisations $a$ and $b$, respectively. 
$S(a b)$ oscillates between 0 and 100 , i.e., the closer $S(a b)$ is to 100 , the greater the similarity between the two organisations will be. Hence, the two extreme cases would be the following:

- $S(a b)=100$ when $X_{i}(a)=X_{i}(b)$ for all $i$, i.e., when the composition of the two organisations is identical.

- $S(a b)=0$ when the composition of $X i(a)$ is totally different from that of $X i(b)$.

This index, however, is limited in that it only allows for the comparison of similarity between two DMUs. Since our study sets out to calculate similarity among various $D M U s$, we attempt to overcome this limitation by calculating a similarity index for each local authority in relation to the rest.

In order to discover whether the level of similarity is higher in organisations classified as efficient in all the defined output specifications, two groups were defined: efficient $D M U s$ on the one hand (with a result of 990 similarity indices), and all the DMUs on the other (with 33.150 indices). The results obtained are summarised in Table 8.

[Table 8 about here]

In order to be able to interpret the results, we tested the null hypothesis of equal averages between the groups against the alternative hypothesis of the difference of averages. A non-parametric sign test was used to carry this out, and the results of which indicated that the null hypothesis of equal averages was not rejected at a significance level of 0.05 . We can therefore conclude that no significant differences exist between 
the budgetary structures of efficient local authorities and the rest of local authorities. In other words, there is no evidence that the specific budgetary structure could cause rigidities, promoting inefficiencies in fund allocation.

We now go on to focus on analysing other external explanatory factors that have an impact on inefficiency. To do this, we try to observe the impact of some socio-economic and financial variables by applying the Tobit censored regression model. This technique has been used by authors such as De Borger et al. (1994), Lall et al. (2000) and Ouellette and Vierstraete (2005), among others, and is used in cases where the dependent variable is censored. In this study, the censored variable is that of the efficiency levels, which cannot be higher than unity. For our purposes, the standard Tobit model can be defined as follows:

$$
\begin{array}{ll}
y_{i}^{*}=x_{i}^{\prime} \beta+u_{i} \\
y_{i}=y_{i}^{*} \quad \text { if } \quad y_{i}^{*}<1 \\
y_{i}=1 \quad \text { if } & y_{i}^{*} \geq 1
\end{array}
$$

where $u_{i}$ is assumed to be the i.i.d. drawings from $\mathrm{N}\left(0, \sigma^{2}\right)$. The latent variable $y_{i}^{*}$ is not directly observable. Its observed counterpart is the efficiency index $y_{i}$. For $y_{i}^{*}$ less than 1 , both $y_{i}$ and $x_{i}$ are observed; while for $y_{i}^{*} \geq 1, x_{i}$ is observed and the $y_{i}$ equals the limit value of 1 . 
In our case, $y_{i}^{*}$ represents efficiency levels (censored variable) and $x_{i}^{\prime}$ are the socioeconomic and financial variables. Specifically, the variables that appear in Table 9 are those taken as independent variables.

[Table 9 about here]

The results obtained from the Tobit regression analysis are shown in Table 10. The results indicate that the socio-economic variables, such as unemployment, level of tourism, economic level ${ }^{6}$, do not significantly affect the level of efficiency in public administrations. However, of all the socio-economic and financial variables included in this study, only the per capita tax revenue, the per capita grants and the level of commercial activity $^{7}$ appear to have any bearing on efficiency levels. The signs obtained are in accordance with intuition: the greater the commercial activity, the more pressure there is on public managers to improve efficiency, whereas the greater security in obtaining public revenues (via revenue raised from taxation), the lower the levels of efficiency. These results can bring about some worthwhile consequences, especially when there is the intention of introducing incentives in order to modify the behaviour of public managers. If this is the case, the introduction of variability in the revenues operates as a factor which encourages a more efficient management and decisionmaking process.

[Table 10 about here]

\footnotetext{
${ }^{6}$ The Spanish Annual Commercial Report (Anuario Comercial de España) takes the municipal per capita disposable household income as the economic level indicator.

${ }^{7}$ This variable is not significant if efficiency is analysed by population bands. However, the relevance of the variable is lower, since it is not as flexible as the "tax revenue" and "grants" variables, which are budgetary variables and therefore more easily modified by public managers.
} 


\section{Conclusions}

This paper analyses the non-parametric frontier efficiency of a sample of Spanish local councils, and in an attempt to distinguish the factors which can be influenced by management decisions from those which are exogenous, an attempt has been made to determinate the factors which may affect the efficiency coefficients.

As a way of presenting a brief summary of the results, conclusions can be outlined as follows:

a. From the comparison of the short-term efficiency (evaluation on a yearly basis) in relation to long-term efficiency evaluation (the aggregation of four years comprising a full term of office for a given political party), statistical evidence of an existing so-called 'political-budgetary cycle' has been found; it consists of the distribution of expenses according to the political cycle calendar (i.e. election times and periods of office for a given political party).

b. Three models defining different output and quality variables have been applied. The quality variables embrace two different perspectives respectively: a) the citizens' evaluation of quality and b) the state of use of public infrastructures. The logical underlying posture is to verify to what extent efficiency and quality are contradictory targets to be achieved. The results show that in our case study, there is no evidence of an artificial increase of efficiency by the degradation of the quality of services. Obviously there are differences among the three models applied, but the 
different numbers of variables defined in each specification partly explains these differences. More specifically, when comparing values from Model DEA 1 (a model that includes no quality variable) with Model DEA 3 (considering all output and quality variables), we observe very limited differences. Our conclusion is that in our sample of Spanish municipalities, the trade-off between productivity and quality is not an important issue. However, this situation has to be verified if we are trying to carry out an efficiency analysis in public services with possible implications on policy making.

c. The general situation is that inefficiencies are not extremely high. More particularly, it has been found that municipalities with a population of between 5,000 and 20,000 inhabitants showed higher global technical efficiency. Strangely enough, when the scale inefficiency is adjusted, larger municipalities are nearer to the frontier. In other words, although technically larger municipalities face decreasing returns to scale, the use of better inputs (qualified staff, better information technology resources etc.) allows them to be closer to the purely technical frontier, irrespective of the output specification.

d. As a possible factor to explain inefficiencies, we test the importance of the budget structure. The hypothesis tested is whether the budget structure, which has certain rigidities due to unavoidable legal compromises for most of the time (strong dependence on some revenues, the structure of the public servant collective, some long-term agreements contracting out specific services...), 
introduces inefficiencies in fund allocation owing to legal restrictions to change in the organisation of services. The conclusion was that no significant differences exist between the budgetary structures of efficient local authorities and the rest of local authorities. In other words, there is no evidence that the specific budgetary structure could cause rigidities, promoting the aforementioned inefficiencies in fund allocation.

e. The per capita tax revenue and the level of per capita grants also affect efficiency levels. The results obtained indicate that organisations with higher tax revenues and/or those receiving higher grants are the most inefficient as far as the management of their resources is concerned. It therefore seems reasonable to expect that a local authority with a high capacity for obtaining resources (through tax revenue and/or grants) would be less motivated to manage them adequately. In contrast, the level of commercial activity has a positive impact on efficiency levels. This can also be observed in the work by Giménez and Prior (2001) on Catalonian local authorities. The authors consider that the local authorities with a higher level of commercial activity subject their local authority managers to greater pressure to administer the services provided in the most efficient way.

In conclusion, we have presented a diagnosis focusing on the fundamental causes promoting inefficiency in a sample of municipalities belonging to the Spanish local government sector. Undoubtedly, a need exists to continue the study and to improve certain factors that have not been adequately considered herein. In our opinion, the most important ramifications are concerned with: a) the introduction of specific cost 
frontiers for each council; b) cost control pertaining to environmental factors and for level of service quality; c) the consideration of a dynamic analysis of the evolution of costs and d) the inclusion of other councils in the analysis, which are either regulated under a different financial environment or have a different territorial organisation.

\section{Acknowledgements}

We would like to thank George Battese, Tim Coelli, Kevin Fox, Quentin Grafton, Joseph Hirschberg and other participants at the Economic Measurement Workshop '02 held at the School of Economics, University of New South Wales, Sydney. Our thanks also go to the referee whose comments considerably improved our paper. Financial support from Fundació Caixa Castelló and the CICYT (SEC2003-04770) are also gratefully acknowledged.

\section{References}

Banker, R.D. and Morey, R.C. (1987) The use of categorical variables in Data Envelopment Analysis. Management Science, 32 (12), 1613-1626.

Chang, H. (1998) Determinants of hospital efficiency: The case of central governmentowned hospitals in Taiwan. Omega, International Journal of Management Science, 26 (2), 307-317.

Cooper, W, Seiford, L. and Tone, K. (2000) Data Envelopment Analysis. A Comprehensive Text with Models, Applications, References and DEA-Solver Software, Kluwer Academic Publishers.

De Borger, B., Kerstens, K., Moesen, W. and Vanneste, J. (1994) Explaining differences in productive efficiency: An application to Belgian municipalities. Public Choice, 80 (3-4), 339-358.

De Borger, B. and Kerstens, K. (1996a) Cost efficiency of Belgian local governments: A comparative analysis of FDH, DEA and econometric approaches. Regional Science and Urban Economics, 26 (2), 145-160. 
(1996b) Radial and Nonradial Measurement of Technical Efficiency: An Empirical Illustration for Belgian Local Governments using an FDH Reference Technology. The Journal of Productivity Analysis, 7, 41-62.

Diez-Ticio, A. and Mancebon, M. (2002) The efficiency of Spanish police service: an application of the multiactivity DEA model. Applied Economics, 34, 351-362.

Finger, J.M. and Kreinin, M.E. (1979) A measure of export similarity and its possible uses. The Economic Journal, 89, December, 905-911.

Fox, K.J. (2001) Efficiency in Public Sector, volume 1 of Studies in productivity and efficiency. Kluwer Academic Publishers, Boston.

Giménez, V.M. and Prior, D. (2001) Cost efficiency frontier evaluation. An application to Catalonian councils. VII Workshop on Efficiency and Productivity Analysis, Oviedo.

Lall, P., Featherstone, A. and Norman, D. (2000) Productive efficiency and growth policies for the Caribbean. Applied Economics, 32, 1483-1493.

MAP (1995) Encuesta de Infraestructuras y Equipamientos Locales. Ministerio de Administraciones Públicas. Madrid.

Noulas, A. and Ketkar, K.W. (1998) Efficient utilization of resources in public schools: A case study of New Yersey. Applied Economics, 30 (10), 1299-1306.

Organisation for Economic Co-Operation and Development (1997) Budgeting For The Future. Paris. OECD Publications.

Ouellette, P. and Vierstraete, V. (2005) An evaluation of efficiency of Québec's school boards using the Data Envelopment Analysis method. Applied Economics, 37, 1643 1653.

Pavlova, M., Groot, W. and Van Merode, G. (2004) Willingness and ability of Bulgarian consumers to pay for improved public health care services. Applied Economics, 36, 1117-1130.

Pedraja-Chaparro, F. and Salinas-Jimenez, J. (1996) An assessment of the efficiency of Spanish courts using DEA. Applied Economics, 28 (11), 1391-1403.

Ray, S.C. (1991) Resource-use efficiency in public school: a study of Connecticut data. Management Science, 37 (12), 1620-1628.

Rogo, K. (1990) Equilibrium Political Budgets Cycles. American Economic Review, 80, 21-36.

Taïrou, A.A. (2000) Does inefficiency explain financial vulnerability of French municipalities? International Conference on Accounting, Auditing \& Management in Public Sector Reforms, EIASM, Zaragoza, 589-599. 
Vanden Eeckaut, P., Tulkens, H. and Jamar, M. A. (1993) Cost efficiency in Belgian municipalities. In Fried, Lovell \& Schimidt (eds.) The Measuring of Productive Efficiency. Techniques and Applications.

Worthington, A.C. and Dollery, B.E. (2000) An empirical survey of frontier efficiency measurement techniques in local government. Local Government Studies, 26, 23-52. 
Table 1. Distribution of responsibilities among central, regional and local administrations

\begin{tabular}{|c|c|c|}
\hline $\begin{array}{c}\text { Central Administration } \\
\text { (Legislation: Spanish Constitution, sec. 149) }\end{array}$ & $\begin{array}{c}\text { Regional Administration } \\
\text { (Legislation: Spanish Constitution, sec. 148) }\end{array}$ & $\begin{array}{l}\text { Local Administration } \\
\text { (Act } 7 / 1985, \text { sec. } 26) \\
\end{array}$ \\
\hline $\begin{array}{l}\text { - Guaranteeing the equality of all Spanish } \\
\text { individuals } \\
\text { - Nationality, immigration and emigration } \\
\text { - International relations } \\
\text { - Defence and administration of Justice } \\
\text { - Commercial, criminal, penitentiary, labour, civil, } \\
\text { intellectual and industrial property, fishes, social } \\
\text { security and protection of the environment } \\
\text { legislation } \\
\text { - General planning of the economic activity. } \\
\text { - General financial affairs and State Debt. } \\
\text { - Development and coordination of scientific } \\
\text { research } \\
\text { - External health } \\
\text { - Sea fishing } \\
\text { - Rail and road transports } \\
\text { - Public works of general interest } \\
\text { - Protection of Spain's cultural and artistic } \\
\text { heritage and national monuments } \\
\text { - Public safety }\end{array}$ & $\begin{array}{l}\quad \text { All Regional Administration } \\
\text { - Woodlands and forestry } \\
\text { - Agriculture and livestock raising } \\
\text { - Inland water fishing } \\
\text { - Urbanisation and housing } \\
\text { - Railways and roads } \\
\text { - Ports and airports that do not engage in commercial } \\
\text { activities } \\
\text { - Use of hydraulic projects and canals } \\
\text { - Environmental protection } \\
\text { - State monuments, cultural development, libraries and } \\
\text { museums } \\
\text { - Self-government institutions } \\
\text { - Local fairs } \\
\text { - The promotion of sports } \\
\text { - Tourism promotion } \\
\quad \text { Some Regional Administration } \\
\text { - Education } \\
\text { - Health and hygiene }\end{array}$ & $\begin{array}{l}\text { - Public street lighting } \\
\text { - Cemetery } \\
\text { - Waste collection } \\
\text { - Street cleaning } \\
\text { - Supply of drinking water to households } \\
\text { - Access to population centres } \\
\text { - Surfacing of public roads } \\
\text { - Food and drink regulations } \\
\text { - Public parks } \\
\text { - Public library } \\
\text { - Market } \\
\text { - Treatment of collected waste } \\
\text { - Civil protection } \\
\text { - Provision of social services } \\
\text { - Fire prevention and extinction } \\
\text { - Public sports facilities } \\
\text { - Abattoir } \\
\text { - Urban passenger transport service } \\
\text { - Environmental protection }\end{array}$ \\
\hline
\end{tabular}

Web page address: http://www.igsap.map.es/cia/dispo/ce_ingles_index.htm 
Table 2. Output indicators based on the minimum services provided

\begin{tabular}{ll}
\hline \multicolumn{1}{c}{ Minimum services provided } & \multicolumn{1}{c}{ Output variables } \\
\hline Public street lighting & Number of lighting points \\
Cemetery & Population \\
Waste collection & Waste collected \\
Street cleaning & Street infrastructure surface area \\
Supply of drinking water to households & Population, street infrastructure surface area \\
Access to population centres & Street infrastructure surface area \\
Surfacing of public roads & Street infrastructure surface area \\
Food and drink regulations & Population \\
\hline \hline
\end{tabular}


Table 3. Descriptive values of the variables

\begin{tabular}{lcccc}
\hline \hline Variable & Mean & Std. Dev. & Min. & Max. \\
\hline Population & 5556.34 & 8641.43 & 23.00 & 55457.00 \\
Number of lighting points & 660.25 & 1198.77 & 13.00 & 12600.00 \\
Tons of waste & 11253.57 & 61166.16 & 14.66 & 654500.00 \\
Street infrastructure surface area & 140432.00 & 205777.20 & 2230.00 & 1308007.00 \\
Registered surface area of public parks & 17937.11 & 32141.90 & 70.00 & 248147.00 \\
Citizens' evaluation of quality: number of votes & 1349.55 & 1760.33 & 11.00 & 8824.00 \\
Technical quality of public infrastructures: dichotomous $d_{1}$ & 0.95 & 0.21 & 0.00 & 1.00 \\
Technical quality of public infrastructures: dichotomous $d_{2}$ & 0.73 & 0.44 & 0.00 & 1.00 \\
\hline \hline
\end{tabular}


Table 4. Results of the Cobb-Douglas Cost Function

\begin{tabular}{|c|c|c|}
\hline Model & Independent Variables & $\begin{array}{c}\beta \\
\text { (t student) }\end{array}$ \\
\hline 1 & Population & $\begin{array}{c}0.956 \\
(52.534)^{*}\end{array}$ \\
\hline \multirow{6}{*}{2} & Number of lighting points & $\begin{array}{c}0.338 \\
(7.187)^{*}\end{array}$ \\
\hline & Tons of waste & $\begin{array}{c}0.153 \\
(4.442)^{*}\end{array}$ \\
\hline & Street infrastructure surface area & $\begin{array}{c}0.147 \\
(2.917)^{*}\end{array}$ \\
\hline & Registered surface area of public parks & $\begin{array}{c}0.066 \\
(2.584)^{*}\end{array}$ \\
\hline & Citizens' evaluation of quality & $\begin{array}{c}0.330 \\
(8.296)^{*}\end{array}$ \\
\hline & Technical quality of public infrastructures & $\begin{array}{c}0.033 \\
(1.523)^{* *}\end{array}$ \\
\hline
\end{tabular}

Model 1: $R^{2}$ adjusted $=0.921$. Model $2: R^{2}$ adjusted $=0.914$

(*) Significant at $1 \%$

(**) Significant at $5 \%$ 
Table 5. Global technical efficiency coefficients

\begin{tabular}{cccccccc}
\hline \hline $\begin{array}{c}\text { DEA } \\
\text { models }\end{array}$ & Years & Mean & Std. Dev. & Min & Max & $\begin{array}{c}\text { \% efficient } \\
\text { DMUs }\end{array}$ & $\begin{array}{c}\text { \% inefficient } \\
\text { DMUs }\end{array}$ \\
\hline & 1992 & 66.66 & 20.74 & 5.18 & 100 & $14.67 \%$ & $85.33 \%$ \\
DEA 1 & 1993 & 71.33 & 19.37 & 15.93 & 100 & $15.83 \%$ & $84.17 \%$ \\
& 1994 & 72.73 & 19.16 & 10.79 & 100 & $11.97 \%$ & $88.03 \%$ \\
& 1995 & 73.06 & 19.59 & 9.09 & 100 & $17.37 \%$ & $82.63 \%$ \\
& $1992-95$ & 75.42 & 18.03 & 23.96 & 100 & $17.05 \%$ & $82.95 \%$ \\
\hline & 1992 & 62.25 & 20.69 & 5.18 & 100 & $9.30 \%$ & $90.69 \%$ \\
DEA 2 & 1993 & 66.11 & 20.04 & 15.19 & 100 & $9.69 \%$ & $90.31 \%$ \\
& 1994 & 69.14 & 20.49 & 11.07 & 100 & $9.69 \%$ & $90.31 \%$ \\
& 1995 & 67.64 & 20.74 & 8.71 & 100 & $11.24 \%$ & $88.76 \%$ \\
& $1992-95$ & 69.71 & 19.61 & 16.84 & 100 & $11.67 \%$ & $88.33 \%$ \\
\hline & 1992 & 67.11 & 21.03 & 5.18 & 100 & $15.89 \%$ & $84.11 \%$ \\
DEA 3 & 1993 & 71.52 & 19.41 & 15.93 & 100 & $16.27 \%$ & $83.72 \%$ \\
& 1994 & 73.30 & 19.31 & 10.79 & 100 & $13.17 \%$ & $86.82 \%$ \\
& 1995 & 73.29 & 19.67 & 9.09 & 100 & $18.22 \%$ & $81.78 \%$ \\
\hline \hline
\end{tabular}


Table 6. Pure technical efficiency coefficients

\begin{tabular}{cccccccc}
\hline $\begin{array}{c}\text { DEA } \\
\text { models }\end{array}$ & Years & Mean & Std. Dev. & Min & Max & $\begin{array}{c}\text { \% efficient } \\
\text { DMUs }\end{array}$ & $\begin{array}{c}\text { \% inefficient } \\
\text { DMUs }\end{array}$ \\
\hline & 1992 & 84.18 & 19.21 & 10.89 & 100 & $41.31 \%$ & $58.69 \%$ \\
DEA 1 & 1993 & 86.01 & 17.34 & 23.10 & 100 & $41.70 \%$ & $58.30 \%$ \\
& 1994 & 85.18 & 18.12 & 20.50 & 100 & $41.70 \%$ & $58.30 \%$ \\
& 1995 & 86.03 & 18.15 & 23.68 & 100 & $45.56 \%$ & $54.44 \%$ \\
& $1992-95$ & 85.21 & 17.32 & 24.18 & 100 & $37.21 \%$ & $62.79 \%$ \\
\hline \multirow{2}{*}{ DEA 2 } & 1992 & 75.04 & 21.38 & 11.16 & 100 & $22.86 \%$ & $77.13 \%$ \\
& 1993 & 76.80 & 21.18 & 20.36 & 100 & $24.81 \%$ & $75.19 \%$ \\
& 1995 & 77.41 & 21.28 & 18.56 & 100 & $25.96 \%$ & $74.03 \%$ \\
& $1992-95$ & 76.83 & 22.29 & 14.86 & 100 & $30.62 \%$ & $69.38 \%$ \\
DEA 3 & 1992 & 88.56 & 19.83 & 18.52 & 100 & $23.64 \%$ & $76.35 \%$ \\
& 1993 & 88.65 & 15.92 & 10.89 & 100 & $55.04 \%$ & $44.96 \%$ \\
& 1994 & 89.67 & 16.03 & 36.24 & 100 & $49.81 \%$ & $50.19 \%$ \\
& $1992-95$ & 89.92 & 16.08 & 28.75 & 100 & $56.98 \%$ & $43.02 \%$ \\
\hline \hline
\end{tabular}


Table 7. Scale Efficiency coefficients

\begin{tabular}{|c|c|c|c|c|c|c|c|}
\hline $\begin{array}{c}\text { DEA } \\
\text { models }\end{array}$ & Years & Mean & Std. Dev. & Min & Max & $\begin{array}{c}\text { \% efficient } \\
\text { DMUs }\end{array}$ & $\begin{array}{c}\% \text { inefficient } \\
\text { DMUs }\end{array}$ \\
\hline \multirow{5}{*}{ DEA 1} & 1992 & 79.40 & 16.82 & 26.00 & 100 & $14.73 \%$ & $85.27 \%$ \\
\hline & 1993 & 83.13 & 14.22 & 27.51 & 100 & $15.89 \%$ & $84.11 \%$ \\
\hline & 1994 & 85.71 & 13.92 & 27.51 & 100 & $12.02 \%$ & $87.98 \%$ \\
\hline & 1995 & 85.30 & 14.71 & 25.64 & 100 & $18.22 \%$ & $81.78 \%$ \\
\hline & $1992-95$ & 88.77 & 11.75 & 50.41 & 100 & $17.83 \%$ & $82.17 \%$ \\
\hline \multirow{5}{*}{ DEA 2} & 1992 & 83.26 & 14.30 & 25.28 & 100 & $12.02 \%$ & $97.98 \%$ \\
\hline & 1993 & 86.60 & 12.29 & 48.95 & 100 & $13.95 \%$ & $86.05 \%$ \\
\hline & 1994 & 89.66 & 12.16 & 37.15 & 100 & $15.50 \%$ & $84.50 \%$ \\
\hline & 1995 & 88.62 & 13.19 & 30.60 & 100 & $22.86 \%$ & $77.14 \%$ \\
\hline & $1992-95$ & 92.01 & 10.94 & 39.19 & 100 & $29.07 \%$ & $70.93 \%$ \\
\hline \multirow{5}{*}{ DEA 3} & 1992 & 76.88 & 17.92 & 23.72 & 100 & $15.89 \%$ & $84.11 \%$ \\
\hline & 1993 & 80.64 & 15.16 & 27.37 & 100 & $16.28 \%$ & $83.72 \%$ \\
\hline & 1994 & 81.67 & 15.42 & 27.51 & 100 & $12.79 \%$ & $87.21 \%$ \\
\hline & 1995 & 81.47 & 15.83 & 23.28 & 100 & $18.21 \%$ & $81.79 \%$ \\
\hline & $1992-95$ & 85.02 & 14.06 & 33.22 & 100 & $18.22 \%$ & $81.78 \%$ \\
\hline
\end{tabular}


Table 8. Descriptive values of similarity indices

\begin{tabular}{cccccc}
\hline & \multirow{2}{*}{$\begin{array}{c}\text { Number of } \\
\text { Organisations }\end{array}$} & \multicolumn{2}{c}{ Mean } & \multicolumn{2}{c}{ Std. Dev. } \\
\cline { 3 - 6 } & similarity indices & Expenditures & Revenues & Expenditures & Revenues \\
\hline Total & 33,150 & 68.77 & 73.47 & 15.58 & 13.54 \\
Efficient & 990 & 67.54 & 65.74 & 17.68 & 16.74 \\
\hline \hline
\end{tabular}


Table 9. Socio-economic and financial variables

\begin{tabular}{llc}
\hline \hline \multicolumn{1}{c}{ Variable } & \multicolumn{1}{c}{ Definition } & FV/SV \\
\hline TAX REVENUES & Tax revenue / Number inhabitants & FV \\
GRANTS & Grants / Number inhabitants & FV \\
FIN. LIABILITIES & Financial liabilities / Number inhabitants & FV \\
UNEMPLOYMENT & \% Unemployment / Legal population & SV \\
TOURISM & Tourism index & SV \\
COMMERCIAL & Level of commercial activity & $\mathrm{SV}$ \\
ECON. LEVEL & Economic level & $\mathrm{SV}$
\end{tabular}

FV: Financial variables

SV: Socio-economic variables 
Table 10. Determining factors of efficiency levels: Tobit results

\begin{tabular}{lccc}
\hline \hline & $\begin{array}{c}\text { DEA 1 } \\
(5 \text { Outputs) }\end{array}$ & $\begin{array}{c}\text { DEA 2 } \\
(3 \text { Outputs })\end{array}$ & $\begin{array}{c}\text { DEA 3 } \\
(6 \text { Outputs })\end{array}$ \\
\hline TAX REVENUES & -0.679 & -0.110 & -0.056 \\
& $(-0.885)^{*}$ & $(-5.557)^{*}$ & $(-2.048)^{* *}$ \\
GRANTS & -0.115 & -0.131 & -0.164 \\
& $(-3.360)^{*}$ & $(-4.468)^{*}$ & $(-4.127)^{*}$ \\
FIN. LIABILITIES & 0.147 & -0.111 & 0.118 \\
& $(1.824)$ & $(-1.715)$ & $(1.243)$ \\
UNEMPLOYMENT & -0.746 & -0.396 & -0.382 \\
& $(-0.539)$ & $(-0.332)$ & $(-0.231)$ \\
TOURISM & -0.077 & -0.098 & -0.743 \\
& $(-1.275)$ & $(-1.875)$ & $(-1.006)$ \\
COMMERCIAL & 0.094 & 0.159 & 0.124 \\
& $(2.110)^{* *}$ & $(4.021)^{*}$ & $(2.121)^{* *}$ \\
ECON. LEVEL & -2.430 & -1.467 & -1.530 \\
& $(-1.295)$ & $(-0.920)$ & $(-0.686)$ \\
CONSTANT & 120.29 & 120.38 & 126.04 \\
& $(11.673)^{*}$ & $(13.757)^{*}$ & $(10.188)^{*}$ \\
\hline \hline
\end{tabular}

The figures brackets are $\mathrm{t}$ statistics.

(*) Significant at $1 \%$

(**) Significant at $5 \%$ 


\section{Graph 1}

Breakdown of efficiency by population bands

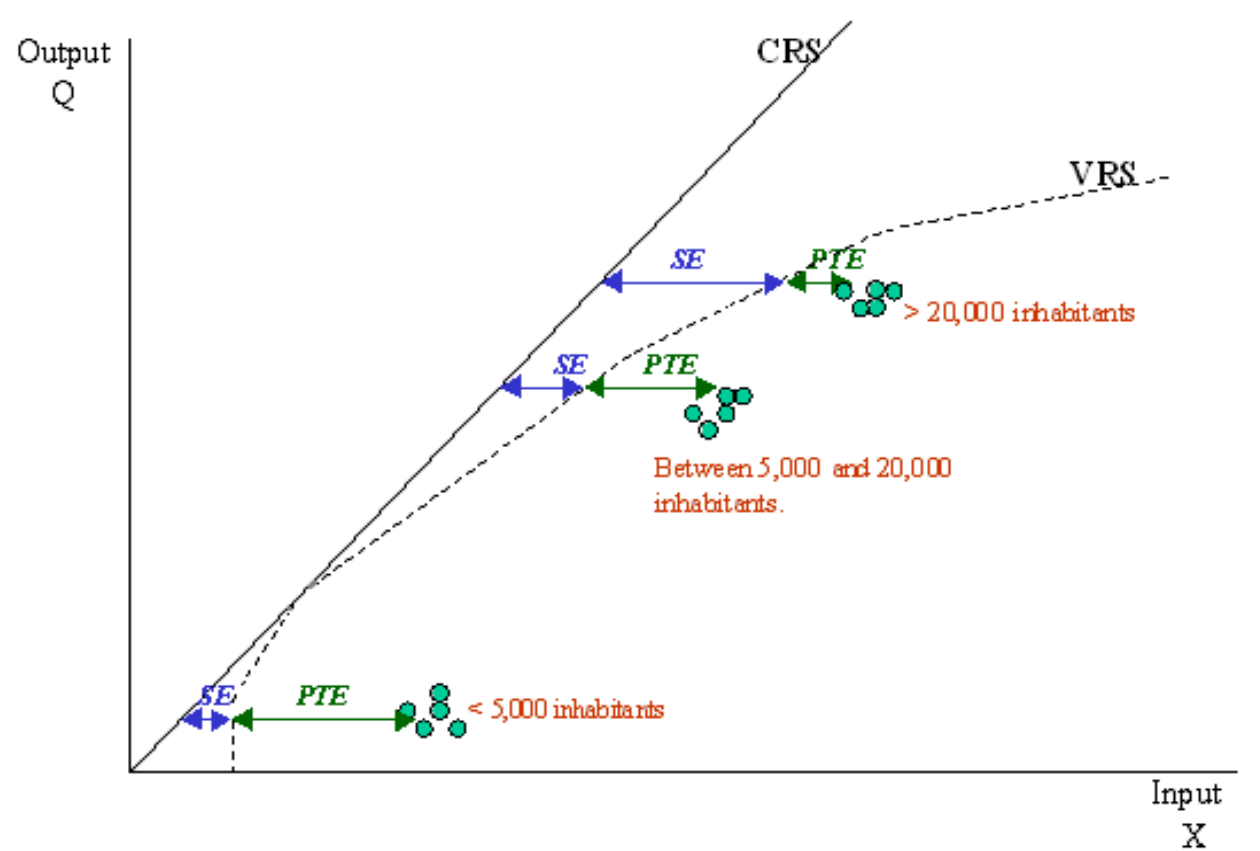

VRS: Variable Returns to Scale CRS: Constant Returns to Scale

SE: Scale Efficiency

PTE: Pure Technical Efficiency 